\title{
DIE ROLPING VAN DIE STAAT T.O.V. DIE ONDERWYS EN KULTUUR IN DIE REPUBLIEK VAN SUID-AFRIKA
}

My toespraak verplaas my na die dae van my ministerskap van Nasionale Opvoeding, waarby Kultuur en Onderwys inbegrepe is. Wat ek nou daarvan sal sê bly my oortuiging, net soos dit enkele maande gelede in my vorige hoedanigheid was.

\section{Kultur}

By die oorweging van die begrip kultuur, moet onderskei word tussen objektiewe kultuur en subjektiewe kultuur.

\section{(a) Objektiewe kultuur}

Deur objektiewe kultuur word bedoel die geheel van die waardes waarin 'n samelewing gestalte aangeneem het. Dit gaan hier om die realiteite wat grotendeels uit die verlede afkomstig is en waarin ons veral skoonheidswaardes en elemente van waarheid in die wetenskap na vore sien kom. Dit bring vir ons die lewenstyl, lewenserns en lewenswysheid van 'n volk. In een woord tot die objektiewe kultuur behoort, hoe 'n groep mense die lewensproblematiek tegemoet gaan.

Hoe relatief die objektiewe kultuur ook al mag wees, staan dit vas dat bevolkingsgroepe op uitdruklike wyse vashou aan hulle eie objektiewe kultuur. Dit is prakties uitgesluit dat ' $n$ bepaalde volkskultuur hom op blywende wyse sou laat verdring. Inteendeel, die omgekeerde is waar. Daar is verskeie voorbeelde van klein volksgemeenskappe, wat ook na jarelange kultuuroorheersing daarin geslaag het om hulle uit die greep van die oorheersende kultuur los te wikkel om hulle eie wyse "van te wees" op verfynde vlak te belewe.

Ons eie geskiedenis toon ook 'n goeie voorbeeld.

\section{(b) Subjektiewe kultuur}

Hier gaan dit nie om die totaliteit van waardes in 'n volksgemeenskap nie. Hier staan ons voor die individuele integrasie van lede van die volksgemeenskap in die objektiewe kultuur.

Hulpmiddels om dit te bewerkstellig is die formele on- 
derwys en opvoeding, die informele opvoeding buite skoolverband en die groot rol wat die gesinsverband speel om die integrasie by die volksverband te bewerkstellig.

Die objektiewe en subjektiewe kultuur is twee kante van een en dieselfde verfyningsmetodiek. Aan die een kant verskyn clie resultaat van wat deur voorgaande generasies gerealiseer en aan die huidige samelewing oorgedra is. Aan die ander kant verskyn die inspanninge van die aktuele generasie om hulle op ' $n$ eietydse wyse in die bestaande kultuurprogram te integreer.

Baie kortliks het ek probeer om met 'n paar riglyne aan te dui hoe wyd Kultuur sy arms strek en dat dit in werklikheid alles insluit wat 'n volk se lewens- en wêreldbeskouing as basis vorm.

Nou duik die vraag onmiddellik op wat die roeping van die Staat ten opsigte van die Kultuur en Onderwys is. En dan wil ek met 'n Algemene Stelling begin:

Die Staat is ook die bewaker en bevorderaar van die kultuurbestemming van sy onderdane in die algemeen en van die organies-historiese Suid-Afrikaanse volk in die besonder.

Hiermee sny ek baie belangrike uitgangspunte aan wat ek soos volg formuleer:

(i) Ten eerste moet die gedagte van Staatsneutralisme i.v.m. geestelik-kulturele goedere verwerp word.

Die Staat, soos trouens alle samelewingsverbande, moet hom ook onder die dissipline van die Woord van God stel. Daarom het die Staat ook die duidelike opdrag om Christelik te wees en in sy huishouding toe te sien dat die orde van God gedien moet word op die kulturele akker.

Ek moet hier ernstig waarsku teen 'n wêreldneiging, wat ook soms by sekere van ons mense posvat, en dit is dat staatsneutralisme die ideaal is. Dit is mense hierdie wat hoegenaamd geen staatsinmenging duld nie en veral by die verskillende soorte van kunste die kreet aangehef het dat „by die kuns gaan dit net om die kuns". Dit mag nie. Dis nie vryheid nie. Dit kom neer op ongebonde bandeloosheid sonder inagneming van die Christelike begrensing wat aan die begrip vryheid gestel is.

(ii) Ten tweede moet $\mathrm{u}$ oplet dat my stelling lui dat die Staat bewaker en bevorderaar is van die kultuur van al die onderdane, maar in die besonder van die Suid-Afrikaanse volk. 
Toe ek aan die begin van die jaar wetgewing in die parlement deurgeloods het om alle kultuuraangeleenthede te koördineer en te aktiveer, het ek dit ondubbelsinnig gestel dat die Afrikaner- en Engelstalige kulture baie in gemeen het en tog tipiese onderlinge verskille toon. Beide word deur die Staat erken en hoewel dit as gevolg van die wetgewing onder één sambreel geplaas word, bly dit in sy ontwikkeling apart met dien verstande dat punte van ooreenkoms waardeer en uitgebou moet word.

By sekere van ons eie mense het daar 'n mate van verwarring ontstaan, as sou die Staat spesifiek die Afrikaanse Volkskultuur moet uitsonder en dit oorlaat aan die Afrikaanse kultuurorganisasies.

Toegegee: die Staat kan en mag nie, kragtens sy wese, eksklusief op die Afrikaanse kultuur toespits nie, want hy vind sy taak juis in gelykberegtiging en beskerming van die regte van alle bevolkingsgroepe in sy gebicd. Verder toegegee, en ek wil dit selfs beklemtoon, dat die Afrikaanse kultuurorganisasies in die besonder en veral vandag, die duidelike roeping het tot toespitsing op die bevordering van die Afrikaanse kultuur. Maar dit alles ontneem die verpligting nie van die Staat om die Afrikaner-volkskultuur jaloers te bewaak en uit te bou nie, want die Afrikanervolk vorm die organisme in Suid-Afrika en in die Afrikanerkultuurgoedere is die tradisie van Suid-Afrika en sy toekoms in 'n groot mate vervat.

Ek herhaal dat die Staat nie voorkeure mag gee nie, maar dat hy alles behalwe onthef is van die verbondenheid en verpligtings aan die Afrikaanse Volkskultuur.

Verder wil ek beklemtoon dat, kragtens ons beginsel, die Staat sy eie terrein het, ook wat die onderwys en kultuur betref.

Daar mag geen grensoorskryding plaasvind nie. Ons tyd word gekenmerk deur die Sosialisme waarin owerheidsbemoeiing op verskillende terreine steeds toeneem. Ons moet ongeoorloofde staatsinmenging op kultuurterrein afwys. Die Staat mag nie beslag lê op die kultuur nie - 'n alleenreg beoefen nie of 'n heerskappy op die kultuurterrein bewerkstellig nie.

Staatsabsolutisme is net so afwysbaar as Staatsneutralisme. 
Vervolgens wil ek spreek oor die Staat en Kultuur. Die Onderwys sonder ons nou af vir latere behandeling.

Vir my is alle arbeid van die Staat wesenlik kultuurhandhawing en kultuuruitbouing, want kultuur is 'n omvattende begrip. Die bydrae van ons verskillende Staatsdepartemente tot ons kultuur is dan ook omvangryk. As ons moet begin opsom word dit: behoud van ons Flora en Fauna in algemene natuurbewaring; uitbouing van ons tegniek en nywerheid; inisiëring en subsidiëring van groot volksmonumente; perssensuur, filmsensuur en boekesensuur ter wille van die godsdienstig-sedelike kodes van ons kultuur; bevordering van sport en ontspanningsvorme; bevordering en subsidiëring van die skone kunste; bevordering en inisiëring en subsidiëring van jeugwerk en kultuurverspreiding d.m.v. vryetydbesteding.

U sou tog seker nie verwag dat ek verder moet opsom nie. Die punt wat ek wil stel is dat ons die Staat moet erken as kultuurdraer, kultuurbeskermer en kultuuruitbouer van groot formaat.

Dat baie van hierdie kultuurarbeid gekoördineer word in 'n Departement van Kultuursake moet deur ons toegejuig word, want daardeur kom daar toegespitste aandag en beplanning. Hierdie Departement beloof dan ook om ' $n$ bolwerk te word teen die dreigende kultuurvervreemding van ons tyd. Hierdie kultuurvervreemding is so wesenlik en van so 'n groot omvang dat ons 'n Staatsdepartement wat beklee is met mag en middele moct toejuig as sterke bondgenoot in hierdie stryd. Ek kan u egter ook verseker dat hierdie Departement sy grense ken en nie partikuliere kulturele inisiatief sal demp nie, maar dit eerder sal bevorder.

Onder die perspektief: "Staat en Kultuur" wil ek nog op twee sake wys.

Ten eerste dat die enkele groot, opvallende en alles beslissende bydrae wat die Staat t.o.v. die kultuur lewer, kulmineer in ons beleid van afsonderlike ontwikkeling. Hierdeur is die jurisdiese grondslag gelê vir die eie kulturele identiteit van ons verskillende volkere, en die behoud van ons historiese waardevolle Christelike kultuur is hierin gewaarborg. Bevordering, offergewilligheid en toewyding t.o.v. hierdie beleid en sy verdere uitvoering is dus wesenlik 'n kulturele opdrag aan owerheid en onderdaan. 
Ten tweede het immigrasie en die staatsbeleid i.v.m. immigrasie ook 'n baie noue verband met die kultuur. Die beginsel is hier dat die Staat alles in sy vermoë doen om kultureel-aanpasbare immigrante na Suid-Afrika te bring. Nie 'n maklike taak nie. Die syfers wek ook dikwels kommer bv. dat die persentasie immigrante gedurende 1963 tot 1968 die volgende vertoon: Brittanje 37.1\%; Portugal 10.4\%; Duitsland 7.6\%; Griekeland 4.1\%; Hierteenoor 'n skamele $3.4 \%$ Nederlanders en $1.1 \%$ Belge. As groot probleem geld hier Blanke kultuurversterking wat lyk asof dit in sig dra 'n tendens tot Afrikaanse kultuurverswakking. Die saak is egter nie só eenvoudig nie, want albei is in ons situasie ewe belangrik.

Dit bly egter die verantwoordelike roeping van die Staat om in sy immigrasiebeleid steeds kultuurversterking, ook in die engere $\sin$ van die woord, ernstig te konsidereer. Ons owerheid se oë is hiervoor nie gesluit nie. Die Staat reken en probeer ook maatreëls daarstel om immigrante kultureel te kondisioneer en te assimileer volgens ons kulturele tradisie. $\mathrm{U}$ moet as kerke, as skole en as gemeenskap op hierdie terrein ' $n$ besondere roeping sien.

Ek wil hierdie afdeling oor Staat en Kultuur afsluit met die oortuiging dat ons huidige Owerheid sy kulturele roeping besef en beoefen en dat ook die Afrikaanse kultuur veilig is in hulle hande - al wil sommige beweer dat dit nié die geval is nie.

\section{Die Staat en die onderwys}

Hier geld ons bekende beginsel van gedeelde verantwoordelikheid, wat beteken dat die ouer, onderwyskorps, kerk en Staat die onderwys sien as 'n gesamentlike projek waarby al die belanghebbendes betrek is, maar nie in gelyke mate nie.

Ons standpunt is dat ons geen Staatskole wil hê nie en ons het dit ook nie in die volle sin van die woord nie. Ons skole is al tot 'n groot mate ouerskole. Wet 39 van 1967 het dan ook meer uitdruklik die plek van die ouer in die onderwys onderstreep as dié van daadwerklike deelname. Hierdie aangeleenthede moet nog nader uitgewerk word. Die groot roeping is egter dat die ouer in die hele georganiseerde en beplande aksie sy regte moet opeis. 
Ek kan die rol van die Staat in die onderwys en opvoeding as volg opsom:

(a) In die heel eerste plek is die Staat geroepe om 'n breedopgestelde, dog duidelike doel vir die onderwys in die volksgemeenskap te stel. Trouens die Staat is dit aan die volksgemeenskap verskuldig om te sorg dat daar deur middel van sy opvoedkundige inrigtings die regte soort mens aan die gemeenskap ten opsigte van kennis, vaardighede, geestelike toerusting, sedelike norme, en ook algemene gesindheid, gelewer sal word.

Dit is dus gebiedend noodsaaklik dat die Staat 'n glasheldere einddoel met die onderwys sal stel, in die lig van die volksaard, tradisies, en die heersende lands- en wêreldomstandighede en -tendense.

Met verwysing na Wet 39 van 1967 is die allesomvattende doel van die onderwys die Christelike en die Nasionale. Die letter van die wet verklaar die skool nou as 'n Christelike inrigting met 'n breë nasionale karakter, sodat die SuidAfrikaanse burger opgevoed sal word tot ' $n$ intelligente, verantwoordelike en allesins volwaardige persoon en landsburger en wat in sy denke en dade gerig is en deur die ewige waarhede van die Heilige Skrif.

Ek kan nie anders nie as om my verbasing uit te spreek dat daar tog mense onder ons Afrikaners is, wat i.p.v. te juig oor hierdie grootse godsdienstig-kulturele triomf i.v.m. ons onderwys, morrend kla dat díe Christelik eintlik maar niks beteken nie, en 'n holle frase is. Ons moet met dankbaarheid hierdie bepaling positief benader en alles veil hê om daaraan gestalte te gee - dit is ons plig as ouers en as Christelikkonfessionele gemeenskap. Dit onthef die Staat egter ook nie. Die Staat het hom verbind aan die Christelike karakter van die onderwys en hy kan tot verantwoording geroep word as hy hier slap laat lê.

(b) Die Staat is geroepe om in sy beraadslaginge en beslissings oor die onderwys hom ook van die kennis en raadgewinge van verteenwoordigende deskundiges op die onderwysgebied te bedien. Dit word gedoen deur middel van die Nasionale Onderwysraad. Verder moet die Staat in noue en simpatieke samewerking met al die instansies, instellings of liggame wat die onderwys vir blankes in die Republiek ad- 
ministreer saam werk t.w. o.a. die departement van Hoër Onderwys, provinsiale administrasies en die universiteite.

(c) As die alles-omvattende instelling in die land, is die Staat geroepe om die onderwys in die volksgemeenskap te koördineer. Dit is dan in die afgelope tyd wel op nasionale vlak gedoen deur middel van die volgende onderwyswette: Nasionale Onderwysbeleid (soos gewysig), Gevorderde Teg. niese Onderwys en Onderwysdienste.

Dit alles vereis en word reeds in die praktyk gedoen om koördinasie te verstewig op nasionale grondslag van leerplanne, kursusse, eksamenstandaarde en navorsing, ondersoek en beplanning op die gebied van die onderwys, met inagneming van die raadsaamheid van die handhawing van die verskeidenheid wat die omstandighede vereis.

(d) Dit is verder seer stellig die roeping van die Staat om toe te sien dat alle kinders en adolessente gelyke onderwysvoorregte geniet. Dit vereis 'n groot verskeidenheid van onderwysinrigtings vir die gewone leerling, vir die gestremde soos die swaksiende, die epileptiese, die dowe e.s.m. In alle staatskole bring dit mee vry onderwys van die grade tot en met St. X.

Die vernaamste middel om gelyke onderwysvoorregte te verseker is 'n opvoedkundige differensiasie van skoolvakke. Dit op sy beurt verseker dat die kind die regte soort onderwys ontvang ooreenkomstig sy vermoëns en aanleg, waarby ook rekening gehou moet word met die leerlinge se belangstelling en die behoeftes van die land.

(e) Die Staat is geroepe om daarvoor te sorg dat die kind sy onderwys deur middel van sy moedertaal sal ontvang.

Die beginsel van die moedertaal as medium van onderrig, waar die moedertaal Afrikaans of Engels is, geld nou vir die hele Republiek.

(f) Tyd ontbreek om volledig op alle aspekte van die Staat se verdere verpligtinge in te gaan en daarom net opsommend die volgende:

Toesighouding oor die inhoud van die onderwys.

Handhawing van die peil van die onderwys, volgens wetenskaplik bepaalde standaarde.

Beproefde deugde moet deur die onderwys verseker word, 
soos: ordelikheid, stiptelikheid, gehoorsaamheid, pligsbetragting, goeie maniere, welvoeglikheid, spaarsaamheid, en regte gesindhede soos goeie burgerskap en vaderlandsliefde.

Regsverhoudinge van diegene wat regstreeks by die skool betrokke is moet die Staat vasstel: die ouer, die leerling en die vakleerling, die onderwyser, die skoolbestuur, ens.

Dit is die Staat se plig om beroepsvoorligting en beroepsleiding aan alle leerlinge te verskaf.

(g) Dit is die roeping van die Staat om toe te sien dat al die onderwysinrigtings onder sy direkte of indirekte beheer oor die regte onderwysers of dosente sal beskik, en daarom het die Staat ook vanjaar met 'n wet die opleiding van onderwysers gekoördineer en op 'n regte grondslag geplaas.

Onderwysers moet mense wees wat sal inpas by die allesomvattende hoofdoel van die onderwys, nl. die ChristelikNasionale.

Die krag wat daar van 'n onderwysstelsel uitgaan, hang af van die gehalte van die geleerdheid en opvoeding, en professionele opleiding van sy onderwysers.

Bepaald is dit die Staat se roeping om te alle tye die welsyn van sy universiteite te verseker want die universiteit is die hoogste onderwysinstelling, die versamel- en kweekplek van wysgerige, wetenskaplike en ander kennis en waardes; hy is die vraagbank cn toetssteen van kennis in die land, die voedingsaar van ons skole en kolleges en van die tegnologie en die nywerheid, die inrigting waarin die intellek en die karakter van die leiers onder die volksgemeenskap gevorm word.

Juis hierom is die universiteit dan by uitstek een van die aanvalspunte van daardie magte wat weet om deur middel van indoktrinering tot innerlike verrotting van die mens en die gemeenskap die bestaande orde omver te gooi en sy eie heerskappy in die plek daarvan te stel. Die opmerklike verantwoordelikheidsin wat ons studente steeds aan die dag gelê het in teenstelling met die luidrugtige klein minderheid wat volgens bekende ideologiese patroon en onder eweneens bekende dekmantels of dwalings, die disrupsie van die universiteitsfunksie poog te bewerkstellig, strek die studentegemeenskap van ons land tot groot eer. 
Die Staat is geroepe om die nodige fondse vir die onderwys in die land te voorsien. Gedurende die boekjaar 1969/70 was die totale voorsiening vir blanke onderwys in die Republiek R294,311,295.

Ek sluit af met dié oortuiging dat ons Staat in sy Kultuur-en Onderwysroeping steeds beweeg in die lyn van ons waardevolle tradisies en steeds soek na die suiwere beginsels en onderskeidinge.

Ek glo dat ons ook steeds krities-waaksaam moet wees t.o.v. die Staat se Kultuur- en Onderwysroeping, maar daarby ook waarderend-dankbaar vir alles wat vermag is en beplan word.

\section{Pretoria.}

J. de Klerk. 